\title{
PENGARUH PENERAPAN MODEL PETA KONSEP DAN PENALARAN TERHADAP KEMAMPUAN MENULIS ESAI MAHASISWA
}

\author{
Herman Budiyono, Puji Tri Aryanti
}

Universitas Jambi, STKIP YPM Bangko, Jambi

\begin{abstract}
This study aims to explain the effect of applying the model to map concepts and reasoning ability of students to write essays High School Teacher Training and Education (STKIP) YPM Bangko, Jambi. The design study is a quasi-experiment, the independent variable (model a concept map), the moderator variable (reasoning), and the dependent variable (the ability to write an essay). $2 \times 2$ factorial design used. One treatment with two levels (X1 and X2) and moderator variables that have two tiers (Y1 and Y2). Subjects were two groups: the experimental class and control class. The results showed that there is the effect of applying the model to map concepts and reasoning ability of students to write essays. The application of the model map concept significantly affect the ability to write an essay, the level of $\alpha=0.05, \mathrm{t}$ count> $\mathrm{t}$ table $(2.946>2.011)$.
\end{abstract}

Keywords: map model concepts, reasoning, ability, essay writing

\begin{abstract}
Abstrak: Penelitian ini bertujuan menjelaskan pengaruh penerapan model peta konsep dan penalaran terhadap kemampuan menulis esai mahasiswa Sekolah Tinggi Keguruan dan Ilmu Pendidikan (STKIP) YPM Bangko, Jambi. Rancangan penelitian yang digunakan adalah quasi-experiment, dengan variabel bebas (model peta konsep), variabel moderator (penalaran), dan variabel terikat (kemampuan menulis esai). Desain yang digunakan faktorial $2 \times 2$. Satu perlakuan dengan dua level $\left(X_{1}\right.$ dan $\left.X_{2}\right)$ dan variabel moderator yang memiliki dua tingkatan $\left(\mathrm{Y}_{1}\right.$ dan $\left.\mathrm{Y}_{2}\right)$. Subjek penelitian adalah dua kelompok, yaitu kelas eksperimen dan kelas kontrol. Hasil penelitian menunjukkan bahwa ada pengaruh penerapan model peta konsep dan penalaran terhadap kemampuan menulis esai mahasiswa. Penerapan model peta konsep berpengaruh secara signifikan terhadap kemampuan menulis esai, taraf $\alpha=0,05$, nilai $t$ hitung $>t$ tabel $(2,946>$ 2,011).
\end{abstract}

Kata kunci: model peta konsep, penalaran, kemampuan, menulis esai

Menulis merupakan salah satu kemampuan berbahasa yang harus dimiliki oleh setiap peserta didik sesuai tingkat dan jenjang pendidikannya. Menulis dapat dimaknai sebagai bentuk penuangan gagasan menggunakan bahasa tulis, dengan maksud memberikan informasi atau penjelasan, meyakinkan atau mempengaruhi, mengisahkan, dan menggambarkan objek kepada orang lain. Hal tersebut sesuai pendapat Gie (2002:3) bahwa menulis adalah segenap 
rangkaian kegiatan seseorang mengungkapkan gagasan dan menyampaikannya melalui bahasa tulis kepada pembaca. Menurut Tarigan (2008:3) menulis merupakan "suatu keterampilan berbahasa yang dipergunakan untuk berkomunikasi secara tidak langsung, tidak bertatap muka dengan orang lain”. Sementara itu, Suparno dan Yunus (2011:1.3) menyatakan bahwa menulis merupakan kegiatan penyampaian pesan (komunikasi) menggunakan bahasa tulis sebagai medianya.

Kemampuan menulis esai merupakan kemampuan penting dan strategis bagi mahasiswa. Melalui esai memungkinkan mahasiswa memberikan kontribusi positif terhadap permasalahan-permasalahan yang terjadi di masyarakat, antara lain dengan cara menuangkan ide-ide cemerlang yang dituangkan dalam tulisan esai. Esai juga dapat menumbuhkan jiwa kritis dan kreatif pada mahasiswa tanpa menimbulkan tindakan anarkis seperti yang sering terjadi di kalangan mahasiswa ketika menyampaikan aspirasi kepada pihak-pihak lain.

Salah satu model pembelajaran yang dapat mengefektifkan pembelajaran menulis adalah model peta konsep (mind map), karena model tersebut dalam penerapannya memiliki kelebihan-kelebihan. Buzan (2013:184) mengatakan bahwa dalam penulisan esai, mind map adalah alat yang sangat bagus untuk membantu menulis esai berstruktur baik dan fokus. Model peta konsep dipandang tepat untuk diterapkan dalam pembelajaran menulis esai, yang tujuannya meningkatkan kemampuan mahasiswa menulis esai. Pembelajaran menulis yang menerapkan model peta konsep dapat (1) membantu penulis melihat argumen secara keseluruhan, (2) membantu menilai secara objektif kelogisan argumen dan struktur esai, (3) membantu merencanakan hal yang akan ditulis, dan (4) membantu memeriksa kebenaran jalur tulisan (Buzan, 2013:185).

Model peta konsep merupakan model pembelajaran yang mengadopsi cara otak menyimpan informasi pada sel syaraf yang bercabang-cabang. Buzan (2013:4) menjelaskan bahwa peta konsep adalah "cara termudah untuk menempatkan informasi ke dalam otak dan mengambil informasi ke luar otak — mind map adalah cara mencatat yang kreatif, efektif, dan secara harfiah akan memetakan pikiran-pikiran kita". Buzan (2013:5) juga menjelaskan keuntungan menggunakan peta konsep dalam pembelajaran, yaitu (1) memberi pandangan menyeluruh pokok masalah atau area yang luas; (2) memungkinkan merencanakan rute bagi ingatan, yaitu mengingat informasi atau fakta lebih mudah dan lebih bisa diandalkan dibandingkan menggunakan teknik mencatat tradisional; (3) mengumpulkan sejumlah data dalam satu tempat; (4) mendorong pemecahan masalah dengan kreasi baru; dan (5) menyenangkan untuk dilihat, dibaca, dicerna, dan diingat.

Menurut Buzan (2013:184) langkah-langkah menulis esai dengan peta konsep adalah sebagai berikut. Pertama, penulis membuat gambar sentral isi esai yang ditulis, memikirkan semua informasi yang telah dikumpulkan, kemudian membiarkan otak "melamunkannya". Penulis bisa menambah cabang "informasi" pada "peta konsep" dan menuliskan kategori utama dari informasi yang telah dikumpulkannya. Kedua, penulis menggambar cabangcabang yang dapat mewakili bagian pendahuluan, argumen utama, dan simpulan. Ketiga, penulis memperhatikan tema-tema yang telah ditulis pada cabang-cabang "informasi" dan memikirkan bagaimana kaitannya. Kalau akan mengerjakan bagian pendahuluan, penulis terlebih dulu menjelajahi cabang "pokok argumen" dengan anak-anak cabangnya untuk membantu membangun tubuh informasi utama naskah. Setelah pokok argumen ditetapkan, bisa mundur dan mengerjakan pendahuluan dan simpulan. Keempat, penulis melangkah mundur dari "peta konsep" untuk memeriksa apakah argumen atau tema esai berjalan maju 
dan terfokus. Kelima, setelah puas dengan peta konsepnya, penulis dapat mulai menulis dengan peta konsep di sisinya dan tetap berada di jalur yang benar.

Keberhasilan mahasiswa dalam pekuliahan menulis tidak hanya ditentukan oleh model pembelajaran yang diterapkan dalam pembelajarannya, tetapi juga dipengaruhi oleh berbagai faktor. Faktor-faktor yang dapat berpengaruh, di antaranya adalah faktor internal mahasiswa. Faktor internal yang krusial terhadap keefektifan penerapan peta konsep pada perkuliahan menulis esai adalah penalaran. Widjono (2012:272) mengemukakan bahwa penalaran mempunyai beberapa pengertian, yaitu (1) proses berpikir logis, sistematis, terorganisir dalam urutan yang saling berhubungan sampai dengan simpulan; (2) menghubunghubungkan fakta atau data sampai dengan suatu simpulan; (3) proses menganalis suatu topik sehingga menghasilkan suatu simpulan atau pengertian baru; (4) mengaji, membahas, atau menganalisis dengan menghubung-hubungkan variabel yang dikaji sampai menghasilkan derajat hubungan atau simpulan; dan (5) pembahasan masalah sampai menghasilkan suatu simpulan berupa pengetahuan atau pengertian baru. Menurut Alek dan Ahmad (2011:195), penalaran adalah "proses pengambilan simpulan (conclusion, inference) dari bahan bukti atau petunjuk (evidence), atau pun yang dianggap bahan bukti atau petunjuk, secara umum ada dua jalan untuk mengambil simpulan, yaitu induksi dan deduksi”.

Penalaran induktif adalah "suatu proses berpikir yang bertolak dari satu atau sejumlah fenomena individual untuk menurunkan suatu simpulan" (Keraf, 2007:43). Oleh Alek dan Ahmad (2011:195) penalaran induktif ditafsirkan sebagai "penalaran yang berawal pada yang khusus dan berakhir pada yang umum". Terdapat tiga jenis penalaran induktif, yakni (a) generalisasi, (b) analogi, dan (c) sebab-akibat. Tentang generalisasi, Keraf (2007:43) mengemukakan bahwa generalisasi adalah proses penalaran yang bertolak dari sejumlah fenomena individual menuju suatu inferensi umum, mencakup semua fenomena itu. Tentang analogi, (Keraf, 2007:48) mengemukakan bahwa analogi adalah proses penalaran yang bertolak dari dua peristiwa khusus yang mirip satu dengan yang lain, kemudian disimpulkan bahwa apa yang berlaku untuk suatu hal akan berlaku pula untuk hal yang lain. Menurut Tarigan (2008:119) analogi adalah suatu perbandingan antara dua hal yang bersamaan dalam beberapa segi dan dianggap bersamaan pula dalam segi-segi lainnya. Tentang penalaran sebab-akibat, Widjono (2012:274) menyatakan bahwa proses penalaran yang bertalian dengan hubungan kausal terjadi apabila sebab (atau sebaliknya) ada, maka akibat (atau sebaliknya) ada. Hubungan sebab-akibat disebut implikasi kausal atau implikasi empirik. Menurut Keraf (2007:51), hubungan kausal berlangsung dalam tiga pola yaitu sebab ke akibat, akibat ke sebab, dan akibat ke akibat.

Penalaran deduktif merupakan proses berpikir bertolak dari gagasan yang bersifat umum kemudian diikuti dengan rincian-rincian yang bersifat khusus. Menurut Alek dan Ahmad (2011:196), penalaran deduktif disebut penalaran dari yang umum ke yang khusus. Widjono (2012:276) menyatakan penalaran deduktif adalah proses berpikir logis yang diawali dengan penyajian fakta yang bersifat umum, disertai pembuktian khusus dan diakhiri dengan simpulan khusus yang berupa prinsip, sikap, atau fakta yang berlaku khusus. Terdapat dua macam panalaran deduktif, yaitu silogisme dan entimem. Silogisme adalah bentuk penalaran formal dengan menghubungkan dua proposisi yang berlainan menuju simpulan. Premis merupakan proposisi (putusan) yang menjadi dasar argumentasi. Dalam silogisme terdiri atas tiga bagian, yaitu dua kalimat pertama disebut premis (premis mayor dan minor), kalimat ketiga disebut simpulan. Sementara itu, entimem merupakan bentuk penalaran yang tidak semua unsur proposisinya dinyatakan secara eksplisit. Meskipun dihilangkan, proposisi itu tetap dianggap ada dalam pikiran dan dianggap diketahui oleh orang lain. Sesuai pernyataan 
tersebut, Carney dan Scheer (dalam Warno, 2009:65) berpendapat bahwa entimem adalah "beberapa argumen yang tidak dinyatakan secara penuh, simpulan atau beberapa premisnya sering dihilangkan atau tidak dinyatakan oleh karena sudah jelas yang dimaksudkan”.

Berdasarkan konsep-konsep yang telah dipaparkan di atas, penalaran dalam penelitian ini adalah kesanggupan mahasiswa berpikir secara maksimal menurut pola tertentu (induktif atau deduktif) untuk menghubungkan fakta-fakta atau bukti-bukti yang ada dengan langkahlangkah yang teratur, sistematis (bersifat analitik), dan bertujuan untuk menghasilkan simpulan.

Pendapat di atas mengisyaratkan bahwa kemampuan bernalar seseorang ikut menentukan tingkat kualitas tulisan yang dihasilkan. Pada waktu menulis, penulis berusaha menghubunghubungkan secara logis unsur-unsur yang membangun tulisan. Penulis mengaitkan pengalaman yang telah dimiliki dengan sesuatu yang ditulis dengan memperhatikan aturanaturan tulisan yang baik, seperti penggunaan kosakata, diksi yang tepat, penyusunan struktur kalimat yang tertata rapi, runtut, jelas, dan penerapan kaidah ejaan dan tanda baca. Oleh karena itu, beberapa ide atau gagasan yang tersimpan di benak seseorang akan dengan mudah dan lancar dikomunikasikan kepada orang lain apabila orang tersebut memiliki kemampuan penalaran yang baik.

Berdasarkan uraian di atas, dapat dinyatakan bahwa ada kaitan antara penerapan model pembelajaran dengan hasil pembelajaran menulis esai, yakni kemampuan menulis esai. Pembelajaran menulis esai menggunakan model peta konsep akan mempengaruhi kemampuan menulis esai mahasiswa. Selain itu, kemampuan menulis esai mahasiswa juga dipengaruhi oleh kemampuan bernalarnya. Dengan kata lain, penerapan model peta konsep dan penalaran berpengruh terhadap kemampuan menulis esai mahasiswa.

Esai adalah "sepotong tulisan (karangan pendek) berbentuk prosa tentang suatu masalah" (Procter (Ed.), 1983:372). Esai adalah "karangan prosa yang membahas suatu masalah secara sepintas lalu berdasarkan sudut pandang pribadi penulisnya" (Depdikbud,1995:270). Tulisan esai mengungkapkan persoalan sebatas ketertarikan penulisnya mengenai persoalan tersebut (Djuharie dan Suherli, 2001). Budiyono (2012) menyatakan bahwa esai juga dapat diartikan sebagai sebuah karangan pendek yang utuh. Esai pada penelitian ini merujuk pada sebuah tulisan pendek yang utuh, selanjutnya disebut sebuah tulisan esai (STE). STE terdiri atas beberapa paragraf. Meskipun terdiri atas beberapa paragraf, STE membahas satu topik. Topik yang ada pada STE itu dibagi menjadi beberapa subtopik yang lebih kecil, yang kemudian ditulis dalam beberapa paragraf yang panjangnya sesuai dengan tingkat pentingnya setiap subtopik. Menurut Wahab dan Lestari (1999:49) semua paragraf yang ditulis untuk mengembangkan satu topik besar tersebut diikat menjadi satu oleh paragraf pendahuluan dan paragraf penyimpul.

Setiap esai mempunyai pendahuluan, isi (batang tubuh), dan simpulan (Kirszner \& Mandel, 1980:17-18). STE yang baik, biasanya terdiri atas tiga bagian, yaitu satu paragraf pendahuluan, beberapa paragraf penjelas, dan satu paragraf penyimpul (Wahab \& Lestari, 1999:49). Oleh karena itu, untuk dapat membangun STE yang baik, seorang penulis harus memahami dan dapat menerapkan paragraf-paragraf yang sesuai untuk diterapkan pada pendahuluan, isi, atau penutup (simpulan).

Kualitas kemampuan menulis esai siswa dapat diungkap dari sebuah tulisan esai (STE) yang ia hasilkan. STE berkualitas baik mencerminkan penulisnya (siswa) memiliki kemampuan menulis esai berkualitas baik, begitu juga STE berkualitas cukup mencerminkan siswa yang menulisnya memiliki kemampuan menulis esai berkualitas cukup (Budiyono, 2010). Dengan demikian, kualitas kemampuan menulis esai mahasiswa juga dapat diungkap dari STE yang 
dihasilkan oleh mahasiswa tersebut. Dengan kata lain, STE berkualitas baik, mencerminkan kualitas kemampuan penulisnya juga baik.

Menulis esai merupakan salah satu mata kuliah yang dibelajarkan di Program Studi Pendidikan Bahasa dan Sastra Indonesia (PS-PBSI) Sekolah Tinggi Keguruan dan Ilmu Pendidikan (STKIP) YPM Bangko. Esai adalah karya yang bersudut pandang personal subjektif si penulis. Esai berisi pemikiran yang dipadu dengan pengalaman, observasi lapangan, anekdot, dan pergulatan batin si penulis tentang subjek yang ditulisnya. Esai mengungkapkan gagasan berdasarkan fakta. Oleh karena itu, tulisan esai sangat tepat untuk menggambarkan gagasan seseorang.

Untuk mengetahui dan menguji seberapa besar "pengaruh penerapan model peta konsep dan penalaran terhadap kemampuan menulis esai mahasiswa", peneliti melaksanakan penelitian hal tersebut di STKIP YP Bangko Jambi. Data awal mengindikasikan bahwa mahasiswa PS-PBSI STIKIP YPM Bangko belum mampu menghasilkan tulisan yang baik. Sebagian besar (79\%) tulisan mahasiswa jauh dari sempurna. Tulisannya bercirikan sebagai berikut: (1) tema tulisan kurang fokus, (2) topik pada tiap-tiap paragraf tidak dikembangkan dengan baik, (3) diksi kurang tepat, (4) kalimat-kalimatnya tidak efektif, (5) masih banyak kesalahan ejaan dan tanda baca, dan (6) penalaran dalam tulisan belum baik. Secara umum, tulisan mahasiswa belum baik.

Hipotesis penelitian ini adalah sebagai berikut: (1) terdapat pengaruh model pembelajaran peta konsep terhadap kemampuan menulis esai, (2) terdapat pengaruh model pembelajaran peta konsep terhadap kemampuan menulis esai pada mahasiswa yang memiliki penalaran tinggi, (3) terdapat pengaruh model peta konsep terhadap kemampuan menulis esai pada mahasiswa yang memiliki penalaran rendah, (4) terdapat pengaruh penalaran terhadap kemampuan menulis esai, dan (5) terdapat interaksi model peta konsep dan penalaran dengan kemampuan menulis esai.

\section{METODE}

Penelitian ini menguji pengaruh model peta konsep (variabel bebas) dan penalaran (variabel moderator) terhadap kemampuan menulis esai (variabel terikat). Rancangan yang digunakan quasi eksperimen dengan desain faktorial $2 \times 2$. Satu perlakuan dengan dua level $\left(\mathrm{X}_{1}\right.$ dan $\left.\mathrm{X}_{2}\right)$ dan variabel moderator memiliki dua tingkatan $\left(\mathrm{Y}_{1}\right.$ dan $\left.\mathrm{Y}_{2}\right)$. Subjek penelitian dikelompokkan menjadi dua, yaitu kelas eksperimen (KE) dan kelas kontrol (KK). KE menerapkan "model peta konsep" dan KK menerapkan "model konvensional". Pada penelitian ini, terdapat variabel yang dapat mempengaruhi (memperkuat atau memperlemah) penerapan model peta konsep terhadap kemampuan menulis esai, yaitu penalaran.

Penelitian menggunakan desain Control Group Only Design, dengan rancangan satu kelas ekperimen menerapkan model peta konsep dan satu kelas kontrol menerapkan model konvensional. Masing-masing kelas dibedakan menjadi kelompok mahasiswa berpenalaran tinggi dan kelompok mahasiswa berpenalaran rendah.

Penetapan sampel dengan teknik purposive sampling. Sampelnya adalah mahasiswa peserta kuliah “Menulis Kreatif” pada PS-PBSI Tahun Akademik 2014/2015. Kelas kontrol berjumlah 23 dengan rata-rata kelas 70, 34. Sementara itu, kelas eksperimen berjumlah 28 dengan rata-rata kelas $70,43$.

Pengumpulan data dilakukan dengan instrumen tes penalaran dan tes menulis esai. Analisis data dilakukan dengan uji beda (t-test) dan analisis varian dua arah, dengan terlebih dahulu dilakukan uji prasyarat berupa uji normalitas data dan uji homogenitas variansi. 
Indikator kemampuan penalaran mahasiswa pada penelitian ini mencakup aspek penalaran induktif dan deduktif. Secara rinci, indikator dari tiap-tiap apek tersebut terlihat pada Tabel-1.

Tabel 1 Aspek dan Indikator Penalaran

\begin{tabular}{ll}
\hline Aspek Penalaran & Indikator Penalaran \\
\hline Penalaran Induktif & menarik simpulan dengan cara generalisasi \\
& menghindari salah nalar karena generalisasi sepintas \\
& menarik simpulan dengan cara analogi \\
& menghindari salah nalar karena analogi yang pincang \\
& menarik simpulan dengan cara hubungan kausalitas \\
& menghindari salah nalar karena salah hubungan kausal \\
menarik simpulan dengan silogisme & menarik simpulan dengan entimem \\
& menghindari salah nalar karena tidak mengerti persoalan \\
\hline
\end{tabular}

Indikator kemampuan menulis esai mahasiswa ditunjukkan oleh tingkat kualitas tulisan. Tulisan itu mengungkap suatu masalah dan memberikan rincian gagasan terkait masalahnya. Tulisan esai memiliki unsur-unsur sebagai berikut: (1) pendahuluan, berisi latar belakang informasi terkait masalah yang dibahas; (2) tubuh tulisan, berisi penyajian secara rinci informasi terkait masalah yang dibahas; dan (3) bagian akhir, berisi simpulan atau penyajian kembali ide pokok dan ringkasan tubuh esai. Tulisan esai menggunakan bahasa Indonesia (tatabahasa, kosa kata, dan ejaan dan tanda baca) sesuai kaidah yang berlaku.

Kualitas kemampuan menulis esai mahasiswa diungkap dari kualitas penerapan aspek pembangun tulisan esai mahasiswa tersebut. Indikator kualitas dari penerapan aspek-aspek pembangun tulisan esai tersebut terlihat pada Tabel-2.

\begin{tabular}{|c|c|c|}
\hline \multirow[t]{2}{*}{ No } & \multicolumn{2}{|r|}{ Tulisan Esai } \\
\hline & Aspek Pembangun & Indikator Kualitas \\
\hline 1 & isi & ketepatan (kesesuaian topik dengan uraian isi) \\
\hline 2 & organisasi & $\begin{array}{l}\text { keserasian dan kelengkapan (pendahuluan, isi, dan } \\
\text { penutup) }\end{array}$ \\
\hline 3 & tata bahasa/gramatika & kecermatan dan ketepatan kalimat \\
\hline 4 & kosa kata & ketepatan pilihan kata \\
\hline 5 & ejaan dan tanda baca & ketepatan dan kecermatan penggunaan EYD \\
\hline
\end{tabular}

\section{HASIL PENELITIAN \\ Deskripsi Data}

Data kemampuan menulis esai mahasiswa yang memiliki tingkat penalaran tinggi dan rendah disajikan pada Tabel-3 berikut ini.

Tabel-3

Distribusi Kemampuan Menulis Esai Mahasiswa

\begin{tabular}{llccccc}
\hline Kelas & Tingkat Penalaran & Mean & Std. Deviation & $\mathrm{N}$ & $\mathrm{X}_{\max }$ & $\mathrm{X}_{\min }$ \\
& Tinggi & 78,13 & 7,932 & 16 & 90 & 65 \\
Eksperimen & Rendah & 62,92 & 6,557 & 12 & 75 & 55 \\
& Tinggi & 66,50 & 12,704 & 10 & 80 & 45 \\
\multirow{2}{*}{ Kontrol } & Rendah & 58,85 & 11,393 & 13 & 75 & 40 \\
& Eksperimen & 71,61 & 10,546 & 28 & 90 & 55 \\
Total & Kontrol & 62,17 & 12,324 & 23 & 80 & 40 \\
\hline
\end{tabular}




\section{Analisis Prasyarat}

Analisis prasyarat yang dilakukan adalah uji normalitas dan uji homogenitas terhadap data hasil tes kemampuan menulis esai di kelas yang menerapkan model peta konsep dan yang menerapkan model konvensional. Uji normalitas yang digunakan adalah uji liliefors. Kriteria data berdistribusi normal jika nilai signifikansi yang diperoleh lebih besar daripada taraf nyata 0,05 . Jika nilai signifikansi lebih kecil daripada taraf nyata 0,05 maka data berdistribusi tidak normal. Hasil uji normalitas diperoleh nilai signifikansi dari seluruh data lebih besar daripada taraf nyata 0,05 . Maka, seluruh data berdistribusi normal.

Uji homogenitas menggunakan rumus statistik levene dengan kriteria data dikatakan memiliki variansi yang homogen jika signifikansi yang diperoleh lebih besar daripada taraf nyata 0,05 . Hasil uji homogenitas diperoleh nilai signifikansi dari data kemampuan menulis esai pada kelas eksperimen dan kelas kontrol=0,461; pada kelompok penalaran tinggi=0,213; kelompok penalaran rendah=0,084. Hal itu, menunjukkan bahwa nilai signifikansi yang diperoleh lebih besar daripada taraf nyata 0,05 , maka dapat disimpulkan bahwa data memiliki variansi yang homogen.

\section{Pengujian Hipotesis}

Pengujian hipotesis $1,2,3$, dan 4 pada penelitian ini menggunakan uji-t, sedangkan hipotesis 5 menggunakan analisis variansi dua arah (anava). Uji hipotesis dibantu dengan SPSS 20 for Windows. Hasil uji hipotesis adalah sebagai berikut.

\section{Uji Hipotesis 1}

Hipotesis 1 penelitian ini adalah "terdapat pengaruh penerapan model peta konsep terhadap kemampuan mahasiswa menulis esai". Penghitungan menggunakan uji-t pada taraf $\alpha=0,05$ diperoleh nilai $t$-hitung $=2,946>\mathrm{T}$-tabel $=2,011$; maka hipotesis nol $\left(\mathrm{H}_{\mathrm{O}}\right)$ ditolak dan hipotesis alternatif $\left(\mathrm{H}_{\mathrm{a}}\right)$ diterima.

\section{Uji Hipotesis 2}

Hipotesis 2 penelitian ini adalah "terdapat pengaruh penerapan model peta konsep terhadap kemampuan menulis esai pada mahasiswa berpenalaran tinggi”. Penghitungan menggunakan uji-t pada taraf $\alpha=0,05$ diperoleh nilai $t$-hitung $=2,886>$ T-tabel $=2,064$; maka hipotesis nol $\left(\mathrm{H}_{0}\right)$ ditolak dan hipotesis alternatif $\left(\mathrm{H}_{\mathrm{a}}\right)$ diterima.

\section{Uji Hipotesis 3}

Hipotesis 3 penelitian ini adalah "terdapat pengaruh penerapan model peta konsep terhadap kemampuan menulis esai pada mahasiswa berpenalaran rendah". Penghitungan menggunakan uji-t pada taraf $\alpha=0,05$ diperoleh nilai $t$-hitung $=1,082<T$-tabel $=2,089$; maka hipotesis nol $\left(\mathrm{H}_{0}\right)$ diterima dan hipotesis alternatif $\left(\mathrm{H}_{\mathrm{a}}\right)$ ditolak.

\section{Uji Hipotesis 4}

Hipotesis 4 penelitian ini adalah "terdapat pengaruh penalaran terhadap kemampuan menulis esai mahasiswa". Penghitungan menggunakan uji-t pada taraf $\alpha=0,05$ diperoleh nilai $t$-hitung $=4,403>T$-tabel $=2,011$; maka hipotesis nol $\left(\mathrm{H}_{0}\right)$ ditolak dan hipotesis alternatif $\left(\mathrm{H}_{\mathrm{a}}\right)$ diterima.

\section{Uji Hipotesis 5}


Hipotesis 5 penelitian ini adalah "terdapat interaksi antara model peta konsep dan penalaran terhadap kemampuan menulis esai mahasiswa. Penghitungan menggunakan anava dua arah, diperoleh nilai $F$-hitung $=1,877<F$-tabel $=4,045 ;$ maka, hipotesis nol $\left(\mathrm{H}_{0}\right)$ diterima dan hipotesis alternatif $\left(\mathrm{H}_{\mathrm{a}}\right)$ ditolak.

\section{PEMBAHASAN}

Berdasarkan hasil, hipotesis 1,2 dan 4 pada taraf signifikansi 0,05 ; hipotesis nol $\left(\mathrm{H}_{0}\right)$ ditolak, hipotesis alternatif $\left(\mathrm{H}_{\mathrm{a}}\right)$ diterima. Sementara itu, hipotesis 3 dan 5 , hipotesis nol $\left(\mathrm{H}_{0}\right)$ diterima dan hipotesis alternatif $\left(\mathrm{H}_{\mathrm{a}}\right)$ ditolak. Penyebab diterima atau ditolaknya $\mathrm{H}_{0}$ dijelaskan sebagai berikut.

\section{Pengaruh Penerapan Model Peta Konsep terhadap Kemampuan Menulis Esai Mahasiswa}

Model peta konsep merupakan model pembelajaran yang mengadopsi cara kerja otak menyimpan informasi pada sel syaraf yang bercabang-cabang, terlihat seperti pohon dengan cabang-cabangnya. Model itu diterapkan pada pembelajaran menulis esai dengan cara menyusun catatan dimulai dari tema utama sebagai titik sentral dan tema-tema turunan sebagai cabang-cabangnya serta mencari hubungan antartema turunan. Pada tahap menulis esai peta konsep tersebut berperan sebagai acuan dalam mengembangkan ide setiap paragraf.

Pembelajaran dengan model peta konsep mampu menghadirkan contoh konkret bagaimana menghasilkan tulisan esai dengan teknik yang berbeda dengan belajar menulis yang selama ini diikuti mahasiswa. Mahasiswa tampak terbantu dalam penguasaan konsep atau materi tentang menulis esai maupun pada praktik menulis esai. Hal itu sesuai dengan pendapat Buzan (2013:184) bahwa dalam penulisan esai, peta konsep merupakan alat yang sesuai untuk membantu penulisan esai-esai yang terstruktur baik dan fokus.

Penerapan model peta konsep memberikan pengaruh signifikan terhadap kemampuan menulis esai mahasiswa. Perolehan nilai rata-rata pada kelas eksperimen yang menerapkan model peta konsep $(71,61)$ lebih tinggi daripada kelas kontrol yang menerapkan model konvensional $(62,17)$. Dari uji hipotesis, pada uji perbedaan rata-rata kelompok eksperimen dan kelompok kontrol menunjukkan adanya pengaruh kemampuan berpikir siswa yang belajarnya menggunakan metode peta konsep dan resitasi berbantuan media gambar.

Tingginya perolehan nilai rata-rata pada kelas eksperimen didukung juga dengan terlaksananya pembelajaran menulis esai yang lebih kondusif dibandingkan kelas kontrol. Pada kelas eksperimen, mahasiswa terlihat menikmati, serius, dan senang dengan pembelajaran yang diikuti. Selain itu, mahasiswa terlihat lebih berkonsentrasi dan tidak bosan. Pada tahap latihan menulis esai, mahasiswa terlihat tidak bingung karena sudah mempunyai pokok-pokok pikiran yang akan dikembangkan dalam tulisannya. Mahasiswa tinggal menulis mengikuti alur peta konsep yang ada. Hal itu sesuai dengan pernyataan Buzan (2013:185) tentang keunggulan model peta konsep dalam penulisan esai, yaitu (1) membantu melihat argumen secara keseluruhan, (2) membantu menilai secara objektif apakah argumen dan struktur esai sudah masuk akal, (3) membantu merencanakan apa yang akan ditulis, dan (4) berguna untuk memeriksa atau mengecek kesesuaian jalur tulisan.

Sementara itu, pada kelas kontrol materi tentang penulisan esai disampaikan dalam bentuk ceramah. Mahasiswa menyimak penjelasan dari dosen sehingga keaktifan mahasiswa dalam kelas kurang dan mahasiswa juga terlihat kurang antusias. Memasuki tahap menulis, 
konsentrasi mahasiswa kurang maksimal dan terlihat resah. Ketika mengalami kesulitan, mahasiswa bingung dan memilih untuk melihat tulisan dari teman tanpa memahami.

Esai tulisan mahasiswa pada kelas ekperimen berkualitas cukup baik, organisasi esai lengkap, ada pendahuluan, ada bagian tubuh (isi) esai, dan ada penutup. Hal tersebut terjadi karena pada kelas eksperimen mahasiswa memanfaatkan peta konsep yang memuat secara menyeluruh konsep menulis esai. Sebaliknya, esai tulisan mahasiswa pada kelas kontrol, organisasi isi tulisannya berkualitas kurang baik. Mahasiswa belum mampu membangun tulisan dengan baik, banyak tulisan yang hanya berisi uraian fakta terkait dengan topik tulisan, tanpa ada penilaian dan gagasan terkait fakta tersebut sehingga lebih menyerupai tulisan narasi. Selain itu, ada berapa mahasiswa juga tidak mampu mengakhiri tulisan dengan menyimpulkan gagasan yang telah dipaparkan pada bagian tubuh esai.

Berdasarkan pambahasan tersebut dapat disimpulkan bahwa terdapat pengaruh signifikan penerapan model peta konsep terhadap kemampuan mahasiswa menulis esai. Artinya, pembelajaran menulis esai menerapkan model peta konsep lebih baik daripada pembelajaran menulis esai yang menerapkan model konvensional.

\section{Pengaruh Penerapan Model Pembelajaran Peta Konsep terhadap Kemam-puan Menulis Esai pada Mahasiswa Berpenalaran Tinggi}

Mahasiswa yang berpenalaran tinggi merupakan kelompok mahasiswa yang memiliki kemampuan bernalar lebih tinggi daripada nilai rata-rata kelas berdasarkan hasil tes penalaran. Pada kelas eksperimen, mahasiswa berpenalaran tinggi berjumlah 16 orang. Pada pada kelas kontrol, mahasiswa berpenalaran tinggi berjumlah 10 orang. Rata-rata nilai kemampuan menulis esai mahasiswa berpenalaran tinggi kelas pada eksperimen sebesar 78,13 dan pada kelas kontrol sebesar 66,50. Nilai rata-rata tersebut menunjukkan perbedaan yang signifikan antara kelas ekperimen dan kelas kontrol dengan perolehan nilai sig. 0.005 $<$ taraf signifikansi 0,05. Hasil uji hipotesis juga membuktikan bahwa model peta konsep yang diterapkan pada mahasiswa yang memiliki penalaran tinggi berpengaruh secara signifikan dengan perolehan nilai $t$-hitung $=2,595>t$-tabel $=2,064$ yang berarti hipotesis nol $\left(\mathrm{H}_{0}\right)$ ditolak dan hipoteis alternatif $\left(\mathrm{H}_{\mathrm{a}}\right)$ diterima.

Buzan yang mengembangkan peta konsep tidak menyatakan secara spesifik bahwa peta konsep lebih efektif diterapkan sebagai model belajar dengan pertimbangan kemampuan penalaran. Akan tetapi, penelitian ini telah membuktikan bahwa penerapan model peta konsep berpengaruh secara signifikan terhadap kemampuan menulis esai pada mahasiswa berpenalaran tinggi. Hal itu berarti model peta konsep lebih efektif diterapkan pada mahasiswa berpenalaran tinggi dibandingkan pada mahasiswa berpenalaran rendah. Sesuai dengan hasil penelitian Warno (2009:122) bahwa pembelajaran menulis pada siswa berpenalaran tinggi hasilnya lebih tinggi dibandingkan dengan pembelajaran menulis pada siswa berpenalaran rendah. Artinya, siswa berpenalaran tinggi, keterampilan menulisnya lebih baik daripada siswa berpenalaran rendah.

Berdasarkan uraian di atas, dapat disimpulkan bahwa terdapat pengaruh signifikan penerapan model peta konsep terhadap kemampuan menulis esai pada mahasiswa yang memiliki penalaran tinggi. Artinya, pembelajaran menulis esai yang menggunakan model peta konsep pada mahasiswa berpenalaran tinggi hasilnya lebih baik daripada pembelajaran tersebut menggunakan model konvensional. 


\section{Pengaruh Penerapan Model Pembelajaran Peta Konsep terhadap Kemam-puan Menulis Esai pada Mahasiswa Berpenalaran Rendah}

Mahasiswa berpenalaran rendah merupakan kelompok mahasiswa yang memiliki kemampuan bernalar lebih rendah dari rata-rata kelas berdasarkan hasil tes penalaran. Mahasiswa yang termasuk memiliki penalaran rendah pada kelas eksperimen berjumlah 12 orang, sedangkan pada kelas kontrol 13 orang.

Rata-rata nilai kemampuan menulis esai mahasiswa berpenalaran rendah pada kelas eksperimen: 62,92, sedangkan pada kelas kontrol: 58,85. Nilai rata-rata tersebut tidak menunjukkan perbedaan yang signifikan dengan perolehan nilai signifikansi 0,290 > taraf signifikansi 0,05. Hasil uji hipotesis juga mempertegas hal itu, dengan hasil uji-t diperoleh nilai t-hitung $=1,082<t$-tabel $=2,089$ yang berarti hipotesis nol $\left(\mathrm{H}_{0}\right)$ diterima dan hipoteis alternatif $\left(\mathrm{H}_{\mathrm{a}}\right)$ ditolak.

Tidak efektifnya model peta konsep dalam pembelajaran menulis esai pada mahasiswa berpenalaran rendah juga terlihat pada pelaksanaan pembelajaran. Mahasiswa tampak bingung ketika diminta berlatih menentukan pokok-pokok tulisan esai dalam bentuk peta konsep. Sementara beberapa mahasiswa yang telah berhasil membuat peta konsep, pada saat tahap latihan menulis esai, tidak dimanfaatkan peta konsep tersebut sebagai acuan untuk menulis esai. Mahasiswa belum mampu menempatkan peta konsep yang telah dibuat sebagai bagian dari tahap persiapan menulis esai. Hal itu berdampak pada esai yang dihasilkan juga tidak maksimal yang ditandai dengan gagasan yang tidak tepat, tidak jelas, bahkan tidak ada gagasan yang diungkapkan. Organisasi isi esai juga banyak yang tidak lengkap, misalnya tidak ada bagian pendahuluan, bagian tubuh esai hanya berisi uraian fakta tanpa gagasan, dan tidak ada bagian penutupnya.

Berdasarkan penjelasan di atas, penelitian ini telah membuktikan adanya kelemahan teori peta konsep dalam kaitannya dengan pembelajaran. Model peta konsep belum efektif diterapkan pada pembelajaran menulis esai untuk mahasiswa berpenalaran rendah. Oleh karena itu, tidak terdapat pengaruh penerapan model pembelajaran peta konsep terhadap kemampuan menulis esai pada mahasiswa yang memiliki penalaran rendah.

\section{Pengaruh Penalaran terhadap Kemampuan Menulis Esai Mahasiswa}

Penalaran merupakan kemampuan berpikir logis, sistematis, dan terorgainisir untuk mendapatkan pengetahuan atau simpulan. Hal ini dapat dipahami karena pada hakikatnya penalaran merupakan proses mengambil simpulan dari bahan bukti atau petunjuk (evidence) atau pun yang dianggap bahan bukti atau petunjuk (Moeliono, 1985:124-125). Kegiatan menulis tidak dapat terlepas dari kegitan bernalar. Hal itu selaras dengan pendapat Nurgiyantoro (2001:271) bahwa "keterampilan menulis menghendaki penguasaan berbagai unsur kebahasaan dan unsur di luar bahasa itu sendiri yang akan menjadi isi tulisan. Baik unsur bahasa maupun unsur isi haruslah terjalin sedemikian rupa sehingga menghasilkan tulisan yang runtut dan padu".

Ide seseorang akan mudah dan lancar dikomunikasikan secara tertulis kepada orang lain apabila penulisnya memiliki kemampuan bernalar yang baik. Penulis berpenalaran baik akan berusaha menghubung-hubungkan secara logis unsur-unsur yang membangun tulisan, terutama mengaitkan pengalaman yang telah dimiliki dengan sesuatu yang ditulis dengan memperhatikan aturan-aturan atau aspek tulisan, seperti pemilihan kosakata yang tepat, penyusunan struktur kalimat yang efektif, runtut, jelas, dan penerapan kaidah ejaan dan tanda baca. Temuan pada penelitian ini adalah penalaran berpengaruh secara signifikan terhadap 
kemampuan menulis esai mahasiswa (taraf signifikansi 0,05, diperoleh t-hitung =4,403 > t-tabel $=2,011)$.

\section{Interaksi Penerapan Model Pembelajaran Peta Konsep dan Penalaran dengan Kemampuan Menulis Esai Mahasiswa}

Interaksi merupakan kerja sama dua variabel bebas atau lebih dalam mempengaruhi satu variabel terikat. Interaksi berarti bahwa kerja atau pengaruh dari suatu variabel bebas terhadap suatu variabel terikat, bergantung pada taraf atau tingkat variabel bebas lainnya. Dengan kata lain, interaksi terjadi ketika suatu variabel bebas memiliki efek-efek berbeda terhadap suatu variabel terikat pada berbagai tingkat dari suatu variabel bebas lain.

Hipotesis ke-5 dalam penelitian ini "terdapat interaksi antara model peta konsep dan penalaran terhadap kemampuan menulis esai mahasiswa" tidak dapat dibuktikan. Hasil uji hipotesis, nilai $F$-hitung $=1,877<F$-tabel $=4,045$; berarti hipotesis nol $\left(\mathrm{H}_{0}\right)$ diterima dan hipotesis alternatif $\left(\mathrm{H}_{\mathrm{a}}\right)$ ditolak. Hal itu menunjukkan "tidak terdapat interaksi" antara model peta konsep dan penalaran dengan kemampuan menulis esai mahasiswa.

Diagram garis berikut ini, menunjukkan tidak adanya interaksi antara model peta konsep dan penalaran dalam mempengaruhi kemampuan menulis esai mahasiswa.

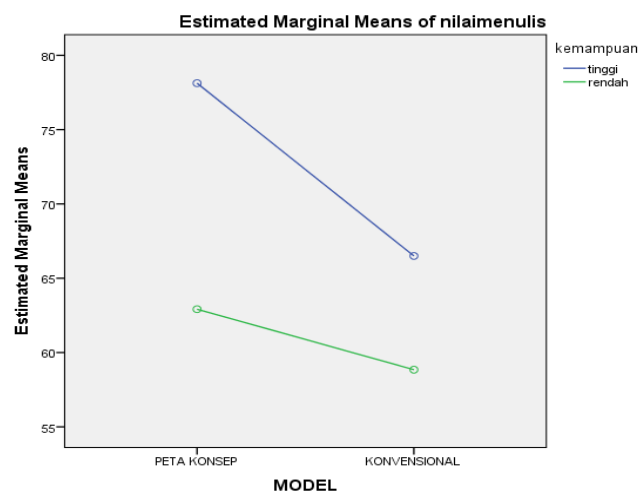

Tidak adanya interaksi antara model pembelajaran dan penalaran dengan kemampuan menulis esai mahasiswa, berarti model peta konsep dapat diterapkan dalam pembelajaran menulis esai tanpa bergantung pada tingkat penalaran mahasiswa. Mahasiswa yang memiliki penalaran tinggi maupun rendah dapat mengikuti pembelajaran dengan model pembelajaran peta konsep. Berdasarkan uraian tersebut disimpulkan bahwa penerapan model peta konsep dalam pembelajaran menulis esai tidak bergantung pada kemampuan penalaran mahasiswa.

\section{SIMPULAN DAN SARAN}

\section{Simpulan}

Berdasarkan hasil penelitian dapat disimpulkan sebagai berikut. Pertama, terdapat pengaruh yang signifikan penerapan model peta konsep terhadap kemampuan menulis esai mahasiswa. Artinya, pembelajaran menulis esai yang menerapkan model peta konsep, kualitasnya lebih baik dibandingkan dengan pembelajaran menulis esai yang menerapkan model konvensional. Kedua, terdapat pengaruh yang signifikan penerapan model peta konsep terhadap kemampuan menulis esai pada mahasiswa yang memiliki penalaran tinggi. Artinya, pembelajaran menulis esai yang menerapkan model peta konsep pada mahasiswa berpenalaran tinggi, kualitasnya lebih baik dibandingkan dengan pembelajaran menulis esai 
pada mahasiswa berpenalaran tinggi yang menerapkan model konvensional. Ketiga, tidak terdapat pengaruh penerapan model peta konsep terhadap kemampuan menulis esai pada mahasiswa yang memiliki penalaran rendah. Artinya, pembelajaran menulis esai yang menerapkan model peta konsep pada mahasiswa berpenalaran rendah, kualitasnya tidak lebih baik dibandingkan dengan pembelajaran menulis esai pada mahasiswa berpenalaran rendah yang menerapkan model konvensional. Keempat, terdapat pengaruh signifikan penalaran terhadap kemampuan menulis esai mahasiswa. Artinya, tingkat kemampuan menulis esai mahasiswa dipengaruhi oleh tingkat kemampuan penalarannya. Kelima, tidak terdapat interaksi antara penerapan model peta konsep dan penalaran dengan kemampuan menulis esai mahasiswa. Artinya, penerapan model peta konsep dalam pemebelajaran menulis esai tidak bergantung pada kemampuan penalaran mahasiswa. Mahasiswa yang memiliki penalaran tinggi atau rendah dapat mengikuti pembelajaran dengan model pembelajaran peta konsep.

\section{Saran}

Berdasarkan simpulan, peneliti memberikan saran kepada guru atau dosen yang menyelenggarakan pembelajaran atau perkuliahan kemampuan menulis esai, harap menerapkan model peta konsep, agar pembelajarannya efektif. Selain itu, siswa atau mahasiswa yang belajar menulis esai perlu dibekali kemampuan penalaran, baik itu penalaran induktif maupun deduktif.

\section{DAFTAR RUJUKAN}

Alek dan Ahmad H. P. 2011. Bahasa Indonesia untuk Perguruan Tinggi. Jakarta: Kencana Prenada Media Grup.

Budiyono, H. 2010. Penilaian Kemampuan Menulis Esai Menggunakan Sistem Penilaian Analitik. Jurnal Ilmiah Universitas Batanghari Jambi, 10(2): 27-36.

Budiyono, H. 2012. Mengembangkan Paragraf Sesuai Fungsi dan Posisi dalam Rangka Menulis Sebuah Tulisan Esai. Pena, 02(2): 13-27.

Buzan, T. 2013. Buku Pintar Mind Map. Jakarta: PT Gramedia Pustaka Utama.

Depdikbud. 1995. Kamus Besar Bahasa Indonesia (KBBI). Jakarta: Balai Pustaka.

Djuharie, O.S. dan Suherlie. (2001). Panduan Membuat Karya Tulis: Resensi, Laporan Buku, Skripsi, Tesis, Artikel, Makalah, Berita, Essei, dll. Bandung: Yrama Widya.

Keraf, G. 2007. Komposisi: Sebuah Pengantar Kemahiran Bahasa. Ende: Nusa Indah.

Kirszner, L. G. and Mandell, S. R. (1980). Patterns for College Writing: A Rhetorical Reader and Guide. New York: St. Martin's Press, Inc.

Moeliono, A. 1985. Kembara Bahasa. Jakarta: Gramedia.

Nurgiyantoro, B. 2001. Penilaian dalam Pengajaran Bahasa dan Sastra. Yogyakarta: BPFE Yogyakarta.

Procter, P. $(E d)$. (1983). Longman Dictionary of Contemporary English. Lomdon: The Pitman Press, Bath.

Suparno dan Yunus. 2011. Keterampilan Menulis. Jakarta: Universitas Terbuka.

Tarigan, H. G. 2008. Menulis Sebagai Satu Keterampilan Berbahasa. Bandung: Angsara.

Wahab, A. dan Lestari, L.A. 1999. Menulis Karya Ilmiah. Surabaya: Airlangga University Press. 
98 | BAHASA DAN SENI, Tahun 44, Nomor 1, Februari 2016

Warno. 2009. Pengaruh Keterampilan Penalaran terhadap Keterampilan Menulis Ditinjau dari Status Sosial Ekonoomi Orang Tua. Tesis tidak diterbitkan, Surakarta: Universitas Sebelas Maret.

Widjono. 2012. Bahasa Indonesia: Mata Kuliah Pengembangan Kepribadian di Perguruan Tinggi. Jakarta: Grasindo. 